Mikołaj J. TOMASZYK

Adam Mickiewicz University in Poznań, Poland

\title{
The determinants and coordination of the message conveyed through the media by the Polish presidency of the Council of the European Union in 2011 - a political science approach
}

\begin{abstract}
1though Poland's presidency of the Council of the European Union $\mathbf{A}_{\text {concluded almost two years ago, this period of Poland coordinating }}$ the work of one of the most significant EU institutions is still the subject of interdisciplinary studies that contribute to the assessment of the new, Lisbon model of European leadership.

The presidency of the European Union can be analyzed from several points of view. Studies into the institutional dimension of the presidency are interesting. They aim to analyze how the Lisbon Treaty modifies the coordination and administration of the Council's work in relations with the entities involved in various thematic blocks and in relations with other institutions involved in the legislative process. This is done in order to compare the theory of the Treaty with the practical operations of the Council, including its new relations with the European Council headed by its standing president and high representative. This is the field for academic reflection on the functions of the presidency and the changes that are determining its current scope.

Another group of studies can be identified with respect to the priorities of the presidency and their actual feasibility, both within the six-month frame of the presidency and in the longer term, that is the eighteen-month period of the trio presidency at the shortest. The direction of these studies is defined by the search for an answer to the question of: (1) how the program of the trio presidency affects the priorities of subsequent states holding the presidency, and (2) to what extent it binds the running agenda of the presidency and consolidates the work of all entities in the Council.

Other interesting topics of studies into the presidency concern the national systems of the coordination and administration of EU policy, the is-
\end{abstract}


sue of how the presidency influences changes in the governance style of EU policy in the member state holding the presidency, what management techniques facilitate obtaining a horizontal outlook on European integration and combining one's national interests with the Community interest from this perspective, to what extent the model of the presidency affects the management style, the organization of human resources, organization of decision-making structures, and coordination of European policy. Studies into management techniques and inter-institutional coordination in order to maximize the efficiency of European policy are conducted in this vein. They examine the kind of political and institutional coalitions the presidency-holding state establishes in order to implement all the items on the presidency agenda, thereby fulfilling all the hopes and expectations placed on the presidency.

All these approaches describe the functions of the presidency, which is understood as a political event which involves political elite and citizens in the course of European affairs. The national actors are involved in European policy, allowing them to build new relations between the realm of national policy and the current policy of the entire Community.

The majority of research conducted in the above-mentioned fields concerns studying how the presidency communicates with the environment. How does it want to use its time and the interest of national and international mass media to improve, correct or create the image of an EU member state? How does it want to help implement its priorities and interests in the EU? How and by what means does it justify its position vis-à-vis various priorities? What political and information steps does it take in order to maximize the chances of achieving understanding among the Council members and interacting with the remaining actors of European integration? These activities complete the member state's political and economic image, being one of the integral elements of its political activity in Europe which can bring future benefits for European policy. They can influence building or reinforcing the relational capital of the state implementing presidency priorities. Therefore, image, public relations and media relations, in particular at the time of the presidency, can either facilitate negotiations or disturb them. When the presidency makes decisions that are influenced by the inflated claims of member states and other institutions, the image of the presiding state in the eyes of its partners in EU decision-making process, institutional actors and EU citizens affects political decisions maximizing or minimizing the chances of the implementation of the EU agenda. The presidency, as the time of fulfilling certain tasks, is 
also the period of particular responsibility for EU matters drawing particular interest of the media. Thereby, it can build or ruin the prestige and status of the country and influence the configuration of member states' interests (Szczerski, 2012, p. 10).

Despite the provisions of the treaties, each presidency can be assessed (Tomaszyk, 2012a; Tomaszyk, Grosse, 2012) as a political, social, systemic and project event. The latter assessment criterion concentrates on comparing the presidency to its project (Szczerski, Dulak, 2012, p. 19). Such comparisons are justified by the following arguments. The presidency is a period of policy coordination set to achieve objectives, and it involves numerous actors in their accomplishment; it is defined by a clear beginning and ending; and it is an unusual and unique event because - as the number of member states increases in line with current policy - the presidency is held once every fourteen years and lasts six months.

This study uses the instrument of comparative analysis and analysis of documents to discuss how the Polish government formulated its communication goals when beginning to prepare for the presidency. How did it define the political message of the presidency? How did it involve its citizens in the activities undertaken by the Polish presidency of the EU Council? What domestic and European factors impacted on the evolution of the message of the presidency? How did the presidency priorities determine its communication goals? How did this message evolve on account of numerous factors?

\section{The determinants and coordination of the message conveyed through the media and the cultural program}

The analysis of the message conveyed by the media, its creation and assumed results leads to a conclusion that numerous functions of the presidency sometimes also involve influencing collective emotions and social expectations, both domestic and foreign. The presidency raises emotions and expectations, and at least indirectly involves citizens, even if they do not perceive the European perspective in the everyday functioning of their state and in their environment.

These were some of the reasons why the government team assigned to prepare the presidency in Poland paid considerable attention to the political messages addressed at Poles and citizens of other member states at the 
time. It was known that the old principle that 'advertising drives trade' could work in this case, too, and that the presidency can first and foremost be a catalyst for a change in the European Union's image among Poles, and of the image of Poles among their neighbors. Therefore, appropriate attention was paid to designing international PR for Poland's presidency. It was obvious that PR is a permanent and inevitable process of social communications in the world involving all kinds of mass media, people (e.g. sportsmen), national and supranational structures, international organizations and transnational corporations, works of art, and artifacts (tools, sports goods, etc.). Thus both domestic and foreign communication was based on a planned and organized government activity in order to create a mutually beneficial relationship and to build a positive image of the state sending this message (Piontek, 2004; Kunczik, 1999; Ryniejska-Kiełdanowicz, 2007; Olędzki, 2001; Dorsch-Jungsberger, 1995).

The following methods were selected out of many to create the national brand at the time of the presidency: operating through information services of the government and ministries as well as through domestic and international news agencies; shaping the image to influence the mass media (study visits of journalists, preparing and delivering information materials, cultural activities conducted abroad by cultural institutes, information centers, foundations, and embassies); promoting science and the arts in Poland; media events in Poland; selling and promoting the best industrial products abroad (sales combined with the promotion of the region of origin); information and promotion campaigns aimed at individual customers, the media, and exerting influence through mass culture products included in the cultural calendar of the presidency in Poland and abroad. In order to meet the needs of such a broad task, a system of institutions in charge of its implementation was set up. They included the Ministry of Culture and National Heritage, Adam Mickiewicz Institute, Institute of Industrial Design, National Audiovisual Institute, the European Information Centre and private entities.

Embarking on the task of developing the assumptions of the domestic and international information campaign in the period of the Polish presidency, the coordination team appointed by the Office of the Committee for European Integration (UKIE), and later taken over by the Ministry of Foreign Affairs, headed by the Government Plenipotentiary, started their work by analyzing previous presidencies and reviewing public opinion polls. The German and Swedish presidencies were an excellent source of experience, since their media communications were deemed model exam- 
ples. The Swedish presidency was, for instance, a pioneer in applying digital media. Swedish good practice embraced a well-designed and coherent web site, emailing, text messaging and Tweets, direct contact with persons in charge of a given theme or meeting, and involving young people in the presidency. There were also examples of presidencies where the communications were unclear, incoherent with the presidency priorities, chaotic, harmful to the image of the country or unable to manage information in a crisis situation. The presidency of the Czech Republic served as an example here, and in particular the artistic installations that in some opinions reproduced the stereotypes that divide Europe (e.g. the David Černý installation).

The catalogue of good practice recommended local campaigns and - as concerns target communication - the Internet was indicated as the main communication tool, program communication was to be profiled, visual communication - expressive and accounting for anniversaries, commemoration days, etc. in the presidency calendar. Media relations were to be characterized by professional and close collaboration with the media and informing about events that involved public opinion. It is worth emphasizing that Polish preparations for the presidency of the EU Council started very early, in 2007. They gained impetus with time, but the preliminary examinations of personnel interested in working in Poland during the presidency (making up its corps), the institutional studies analyzing changes in the system of the presidency following from the Lisbon Treaty, and lobbying for those changes that were advantageous for Poland, drafting the presidency budget and developing a preliminary communications project started as early as at the turn of 2007.

The scale of preparations can be assessed bearing in mind that the Polish presidency services had to prepare approximately 400 meetings in Poland and nearly 2,000 meetings in Brussels during the Polish presidency of the EU Council. The meetings of various working groups, expert meetings, etc. in Poland alone brought together over 30,000 persons who were provided with 10,000 pages of documents translated by 1,160 translators of thirty languages. The agenda of the Danish presidency, in turn, included approximately 1,480 meetings in Brussels and Luxembourg, 46 of which were held at ministerial level and 71 at the level of ambassadors. The 160 meetings organized in Denmark were participated in by a total of 10,268 persons. It should be pointed out that the presidency held 85 official meetings at various levels in the European Parliament (Jensen, Nederguard, 2012). Denmark engaged the national and international press in Danish 
priorities following a principle of far-reaching openness. It was a standard to have daily press conferences, including video-conferences between Copenhagen and Brussels (Jensen, Nederguard, 2012, p. 267). When Poland's Government Plenipotentiary was appointed and the Department of Coordinating Preparations and Support for the Polish Presidency of the Council of the European Union was established, Poland initiated a news portal introducing the Polish presidency and explaining what the presidency is, what powers it has, etc. The decision to start the portal so early on was a right step towards good, reliable media relations on the one hand, and on the other it also brought an educational benefit in the internal discourse about Polish membership of the European Union. This is worth emphasizing since providing such information in advance reduces the scope for misunderstanding and informational chaos. Compared to the Lithuanian presidency (in the second half of 2013) which provided insufficient information about Lithuania's ' 5 minutes' at the helm of the EU Council (a similar portal was launched on June 21, 2013) it can be seen that the Polish team set a high standard for political communication, both planning the message to be broadcast and selecting the means of its multiplication.

Planning the time frame of communications to be spread, three periods were distinguished when the information on Poland's presidency of the EU Council in the second half of 2011 was to be published with differing frequency and in various forms. The first block encompassed the period of 2009-mid-2011. It was assumed to increase awareness (first half of 2009), raise interest (second half of 2009), encourage participation (first half of 2010), win support (second half of 2010), and result in the identification with the presidency in the first half of 2011. A separate catalogue of action was designed for the second half of 2011 and the whole of 2012, when Poland's trio partners of Denmark and Cyprus continued to coordinate the work of the Council.

It was a considerable challenge to coordinate the presentation of basic information on the priorities, successful absorption of EU funds and Polish know-how in counteracting the economic crisis, which was significant both for Polish and international discourse about Poland in the EU. Additionally, the attempt to radically change the quality of communications as compared to the period 2005-2007 to emphasize true European cooperation and partnership was a significant element of the transformation of the Polish discourse in European politics. Poland's political position, combined with its increasing economic status and making the most of the fa- 
vorable circumstances that were independent of Poland, gave it 'prime time' in the EU (Nowak, 2012, p. 6). Therefore, it was necessary to duly develop the guidelines for the information and audiovisual campaign at the planning stage, which was facilitated by the division of tasks between state institutions and the non-government sector.

Among numerous studies that point to the coherence and integrity of the communication, proactive attitude, bilateral communication and provision of information by means of modern media and high pace of providing news, particular attention should be paid to those focusing on the political communications of the state that coordinated the work of the Council. It was correctly assumed that in Poland the presidency would initiate a new stage of informing about European integration. A number of earlier studies, press materials and even academic discourse were dominated by the discussions of the stages of European integration at the accession period, and featuring Poland as an inactive recipient of aid, passive executor of EU directives which are not always understandable to EU citizens, or a state associated with a cocky European policy, symbolized in the opinion of some journalists by the 'mute' diplomacy of former Minister of Foreign Affairs Anna Fotyga. Such an approach, presented by the leading magazines and television debates influenced the perception of Poland's membership of the European Union, and every disappointment resulting from withheld aid, adverse coverage by the Western mass media, reduced subsidies from EU funds, etc. was used by Polish political parties to build their political assets, which did not always involve support for Poland's membership of the EU. Therefore, the change of communication priority from answering the question of: "Am I for or against the EU and how much has the EU given Poland?" to the issue of Poland's role in the EU appeared to be the most significant task in domestic communications. This was in line with the expectations of Poles regarding Poland's presidency of the EU Council. In a survey by the Public Opinion Research Center - CBOS of June 2011, respondents' replies to the question of their expectations of the presidency indicated an improved image of Poland in Europe and globally, and of increased Polish influence on EU policy. The range of presidency-related expectations was completed by a question asking what the most important issues Poland should focus on. Respondents indicated the promotion of our country in the European Union, the good organization and efficient administration of the Council's work and the presentation of Poland's vision of EU activities in the immediate future (CBOS 2011). 
What matters should Poland deal with first during its presidency of the Council of the European Union? - the most frequent replies

Economic matters $-22 \%$ in total including:

- $17 \%$ - improve the economic situation in Poland and the EU, level out the differences in economic development in Poland and other EU countries, develop entrepreneurship;

- $4 \%$ - increase the competitiveness of the EU economy, open markets, ensure free movement of persons, goods and services, strengthen economic cooperation in the EU;

$-2 \%$ - combat the economic crisis and its aftermath, help solve budget problems of states;

- $18 \%$ - improve the labor market situation, reduce unemployment, provide more jobs for the young;

- $12 \%$ - increase living standards, level out the living standards in Poland and other EU states, increase salaries, pensions, and illness allowances;

- 7\% - improve the situation in agriculture - increase subsidies for Polish agriculture, level out subsidies in Poland and the EU, increase profitability of agricultural production;

$-4 \%$ - improve the quality of health care;

- $2 \%$ - combat inflation, stop price rises, reduce prices;

$-2 \%$ - develop infrastructure, build roads;

- $2 \%$ - improve schooling, develop education;

$-2 \%$ - improve social care;

- 5\% - ensure the energy security of Poland and Europe;

- 4\% - address the EU budget, take care of EU funds for Poland, obtain EU subsidies;

- 3\% - ensure the external security of Poland and the EU, combat terrorism;

$-2 \%$-improve international relations, improve cooperation within the EU;

- 2\% - take action within the Eastern Partnership, develop cooperation with East European states;

- $2 \%$ - protect the environment, provide protection against climatic change and natural disasters;

- 5\% - promote Poland in the EU and globally, improve Poland's image;

- 3\% - level out the chances of all EU states, treat all states equally, limit the dominance of large states, support the weaker, ensure solidarity within the EU;

- 2\% - improve Poland's position in the EU;

- 5\% - in general - take care of matters of importance for Poland;

$-2 \%$ - in general - deal with the issues of the whole EU; show regard for the welfare of all EU countries, not only of Poland;

$-26 \%$ - hard to say.

Source: Compiled by the author on the basis of Przed polska prezydencja w Radzie UE, Komunikat z Badań, Centrum Badania Opinii Społecznej, BS/68/2011, Warszawa, June 2011, p. 5.

These answers should be combined with other responses obtained in the same survey, according to which the respondents believe that Poland is a country of medium position and medium influence in the European Union, and are clearly convinced that, irrespective of who is holding the presidency of the EU Council, it is the largest EU members that have the most considerable influence on EU policy, such as Germany, France and Great Britain. 
In its international communication, Poland was supposed to present itself as a predictable actor on European stage, a state that successfully absorbs European funds, has its own ideas of European integration at the time of crisis, and is supportive of further enlargement of the EU. On the occasion of its presidency of the EU Council, Poland was to demonstrate its cultural and economic qualities. Such items as traditional keepsakes and gifts were to promote Polish design, art and culture. "The gifts from the Polish presidency were to demonstrate that Poland can offer goods that follow global trends in design, are innovative and manufactured using the latest technology" (Raport 2012, p. 106). The publications on the presidency were to draw attention to the venues of the meetings, show the people and events which confirm that Poland is a country of rich traditions but at the same time creative, modern and dynamic (Raport 2012, p. 106).

The goals of political and informational communications were to be achieved by public diplomacy and intensive cooperation with the representatives of the mass media (Raport 2012, p. 106). For this purpose, a clear political message of the Polish presidency was developed to reach the stakeholders who were listed as crucial in view of the priorities of the political program (Raport 2012, p. 107). For example, in order to emphasize the image of Poland as a supporter of EU enlargement, the social media showed a short video clip to celebrate Croatia's signing the Accession Treaty. The clip Dobrodosli was broadcast in Croatia and Poland, in particular via Internet sites. In the internal communication, the primary goals were: Poles' understanding and support for the upcoming presidency, reinforcing Poland's positive image in the EU, stimulating pride in Poland and improved self-assessment of Poles, as well as providing a new impetus to the European debate in Poland.

Among the obvious elements that reinforced the narrative about Poland and the Polish presidency was the national and international cultural program of the presidency. In Poland, it accompanied the inauguration of the presidency, informal meetings of the Council and working groups, the events of the Eastern Partnership Summit and the meeting of the leaders of the Sector III organization of the Eastern Partnership. The list of activities that accompanied the presidency domestically was complemented by an interesting element provided by the possibility to apply for financial and honorary support for a local event organized under the patronage of the Polish presidency. Internationally, Poland's activity was coordinated by the Adam Mickiewicz Institute with the aim of reinforcing the country's 
positive image both in other EU member states and in the selected capital cities of non-EU states.

The above-described forms of communication and information about the Polish presidency of the Council of the European Union were significantly influenced by a belief that this period could facilitate a change of priorities in the debate about Poland in the European Union. The coinciding of the presidency with the Euro 2012 football championships, reminiscent of the situation in Germany in 2007, could contribute to a change of how Poles think about themselves, instill a feeling of pride in the important role Poland is playing in the EU and the role as co-host of the European football championships. This expectation was based on a survey conducted in order to determine the new message the media were to broadcast to propagate knowledge about European integration and to increase Polish credibility as a reliable EU actor. This message was continuously reassessed on the basis of the evolution of the priorities and the analysis of new political events, and - to a lesser degree - of institutional conditions.

Right after Poland's presidency ended, the Polish and European press, politicians and academics presented numerous opinions evaluating the activity of the Polish presidency team as regards communication and the ability to build image. Most of them deemed this aspect of the presidency successful, due to the absence of organizational failures, the high efficiency of the organization and risk management by the public administration which coordinated the work of the Council during one of the deeper crises of European integration over the last twenty years (Nowak, 2012), which had to be borne in mind. The following are considered to be the three greatest benefits Poland obtained following the six months of the presidency: Poland's position in the European Union was reinforced, the image of Poland was improved and public administration was Europeanized (Nowak 2012, p. 4). It is worth emphasizing that the specificity of the presidency sets it apart from the activities of the authorities in the realm of public politics, since it is not measured by absolute indicators of the outcome or result (Sczerski, Dulak, 2012, p. 20). This reservation should be applied to the overall assessment of the Polish presidency in the EU Council.

\section{Political and institutional circumstances}

The process of developing the content of communications about the Polish presidency and its priorities was fundamentally influenced by the 
decision to amend the treaties and the implementation of a new model of Council administration. Media coverage emphasizing the administrative or even governing function of the presidency contradicted the actual prerogatives of the so-called Lisbon presidency. Both the stipulations of the treaty and informal conditions that were worked out in the course of successive presidencies affected the selection of priorities by the trio and, consequently, the style of communication. The program of the presidency trio contained quite general goals of the European Union policy which the three member states were endeavoring to work on jointly. The program was adopted in order to provide better cohesion to the Council's work. Apart from setting the agenda, the presidency has other functions, including mediatory and symbolic ones (Jaskulski, 2009). In the Council of the European Union, voting is highly infrequent and takes place in approximately $10-12 \%$ of cases (Jensen, Nederguard, 2012, p. 53); therefore the best method to make decisions is to achieve a common denominator for the political goals of all actors, namely consensus. This is to be ensured by the presidency, which takes into account the different interests of member states. The presiding country has to work in the European interest and include this perspective in the media coverage of its activity.

It is worth mentioning, though, that "promoting one's own specific interests and properly performing the function of an 'honest broker' and impartial mediator are not contradictory" (Jensen, Nederguard, 2012, p. 54). By no means does it mean that exclusively sector policies are concentrated on, instead, close cooperation with the European Council and high representatives in order to support their efforts is the goal. Due to the institutionalization of the European External Action Service (EEAS) (Tannous, 2012), in practice Ministers of Foreign Affairs in Poland and Denmark acted at the junction of the authority of the President of the European Council and high representatives and coordinated most meetings of EU Ministers of Foreign Affairs, or headed EU delegations to non-EU states, (Jensen, Nederguard, 2012). In promoting European interests, the presiding country can covertly lobby for its own national interests. Such activities need to be discreet, and in the new model of the presidency they should be about managing the Council rather than leading it politically. These assumptions did not correspond to the expectations Poles had with respect to Poland's presidency (Ośrodek Analiz Politologicznych Uniwersytetu Warszawskiego, 2012).

Thanks to the conditions of the transition period Poland had an opportunity to present its own direction of EU foreign policy, in particular in re- 
lations with the Eastern Partnership states and in the enlargement policy, in the context provided by Croatia's signing the Accession Treaty. The latter could at least reinforce the image of Poland as a state in favor of maintaining an efficient enlargement policy, which was highly important not only as regards Croatia, but also in relations with Ukraine. Such activities could reinforce Poland's position in the region as well as in the European Union as an expert in relations with the East, which was of particular significance for Poland.

The delayed entry into force and implementation of the Lisbon Treaty affected the selection of priorities of the Polish presidency. It is true that a majority of issues logically followed from the rolling agenda and could have been foreseen and prepared for, at least by way of monitoring the implementation of the priorities of the preceding trio, in particular of the Hungarian presidency, which directly preceded Poland's. Nevertheless, the coordinating team had to take over from a presidency functioning within the principles of the Nice Treaty, and in the transition period of all institutions adapting to the new reality of the Lisbon Treaty. This influenced the coordination of administrative and logistical preparations, the number and scope of priority areas, and the ultimate decision whether to adopt the Brussels, national, or mixed model of the presidency. This, in turn, determined the political communications, which could have focused on the external or internal aspects of EU activities under the Nice model, whereas under the Lisbon model the message was frequently more material and concentrated on the efficient operations of the EU Council, but failed to reinforce the image by organizing such events as prestigious summits of the EU-USA, EU-China or EU-Russian Federation.

The fact that international activity may generate splendor, which is so desired in domestic political reality, could be seen in German Chancellor Angela Merkel or French President Nicolas Sarkozy. Given the context of parliamentary elections to be held in Poland during the presidency, the ruling party could have wanted to improve its ratings with its style of presidency coordination. The Polish Prime Minister had a chance to shape his image as that of a pro-European politician efficiently implementing the EU agenda at the time of his government holding the presidency of the EU Council. The potential successes of the presidency could be used in the election campaign preceding the parliamentary elections, as exemplified by Commissioner Lewandowski taking part in an election spot where he referred to the financial resources earmarked for Poland in the multiannual EU budget. Such activities contradicted the principles of good presidency, 
diminishing the credibility of the Polish Commissioner, whose function required him to look at the Union in a horizontal rather than vertical perspective, not acting in the interest of his country of origin. This could have also undermined lobbying for Polish priorities and led to accusations of Poland having unclear relations with the European Commission.

Poles seemed to subconsciously pay attention to these aspects in the communications about the presidency, as they probably expected improved Poland-EU relations, fostered by associating the presidency with such adjectives as efficient, progressive and innovative (MediaMon, 2012).

One of the principles of good presidency does not allow for its coinciding with parliamentary elections scheduled in the presiding country. Good practice shows that the presidency requires political tranquility and concentration on European issues. An election campaign organized during a presidency can interfere with a Prime Minister's activity in the European forum and reduce his political credibility in the eyes of the 26 leaders of member states. The parliamentary elections in the second half of 2011 could not have been foreseen in early 2007 when the agenda of the presidency was determined. The Polish political calendar scheduled the parliamentary elections for 2009 at that time. This timetable, however, was disturbed by the shortened term of the Sejm and Senate and the consequent elections in the second half of 2011. The authors of studies assessing the Polish presidency claim that the elections allegedly did not have any impact on the course of the Polish presidency, but the presidency did have an impact on the results of the election. Additionally, it seems that the election campaign of all political forces could have overshadowed the domestic coverage of the presidency, adversely affecting its assessment by Polish society. It was deemed an unnecessary awkwardness that the election spot of Civic Platform (PO) featured the President of the European Parliament Jerzy Buzek and Commissioner for Financial Programming and the Budget Janusz Lewandowski.

It would be difficult, however, to accuse the Polish Prime Minister and the ministers working in the crucial bodies of the Council of committing themselves to national parliamentary elections, thereby neglecting their six-month responsibilities in the Union. After all, Belgium held its eleventh presidency in the depths of a government crisis, which was overcome as late as the fourth quarter of 2010 , so Polish ministers headed by the Prime Minister could combine the election campaign with presidency matters. The more so, as has already been mentioned, as the range of issues that needed to be coordinated had shrunk, becoming more adminis- 
trative and technical. Yet, the election campaign may have seemed to overshadow the Polish presidency of the Council, which did not serve the purposes of achieving the well-determined internal communication goals.

The sele ction of the Polish priorities and their presentation was influenced by the program of the 18-month trio presidency of Poland, Denmark and Cyprus. It should be emphasized that all three states started collaborating much earlier than the calendar of the presidency would require. The Prime Ministers of Poland and Denmark and President of Cyprus were aware that the period of their coordination of the work of the Council had to result in decisions programming the activities of the entire European Union until 2020 at the earliest, and in some areas much longer than that. The latter primarily included achieving consent on the political priorities of the multiannual financial frameworks of the EU, implementation of ambitious goals assumed by the Europe 2020 strategy with respect to the change of climate and energy policy, and the EU enlargement process. The ultimate shape of the priorities, which could not have been drafted 'at the eleventh hour' but had to be developed and implemented well in advance, was to a large extent worked out thanks to the coordination meetings of the presidency trio, the development of and reference to the "program index cards', meetings of external consultants to Polish presidency and the invaluable relation capital of Poland in the EU, which helped to lobby for such prioritization that was desirable from the Polish point of view.

The bodies preparing the presidency of the largest state in the presidency trio could not have overlooked the priorities of earlier presidencies and the degree of advancement in such areas as the Eastern Partnership, EU multiannual budget, 'six-pack' consensus, or the new European patent. The significance of Central and Eastern Europe in the process of European integration could be emphasized all year 2011 round, when two CEE states, Hungary and Poland, coordinated the work of one of the most important EU institutions.

\section{External factors}

Among the many determinants of the political communications of the Polish presidency of the EU Council, the global and regional economic crisis cannot be ignored. Poland, as a state outside the euro zone and in favor of a stricter discipline of public finance at EU level, had to work out a joint model of European growth until 2020 and try to change the narra- 
tive about the aftermath of the crisis for the entire EU. It appears that it was the crisis in the Schengen zone, the crisis in euro zone, combined with a crisis wave in the direct vicinity of the EU that shaped the message of Poland in the EU. The underlying leitmotif of the Polish presidency was to revive EU solidarity. European solidarity laying the foundations of the peaceful coexistence of Union states was to provide the basis for Poland's image as a country coping well with the economic crisis, both thanks to the stimulus EU resources provided to infrastructural investment and its internal demand, which ultimately brings benefits to the 'old' EU states restoring a portion of the EU budget spent in Poland via the connections in the internal market. European solidarity as a principle of integration was to demonstrate to all EU members that the crisis could be overcome together, avoiding further divisions that would deepen the existing differences related to different paces of integration in various fields.

The Polish presidency tried to muffle the opinions that integration is becoming fragmented with a restored Union solidarity. By this token, the mainstream multipliers of political communications had to convince Poland's Western partners and their citizens that European solidarity did not stand for the requirement to subsidize enlargement policy, but was a crucial principle in building the anti-crisis policy of fiscal federalization of euro zone and its potential members. Instilling this belief and a favorable atmosphere for the pro-investment budget policy of the EU in the European Parliament and European Commission could have become the greatest success of the Polish presidency. The presidency was responsible for the political climate for the talks on the subsidies to be allocated for the priorities of the EU budget until 2020. This was a part of an anti-crisis message expressed, for example, in the commitment of the Polish presidency team in the work on the 'six-pack', post-2013 Multiannual Financial Frameworks, and in many other fields.

Poland's efforts at the time seemed to have been overshadowed, however, by the 'Merkozy' duo active in the European arena, the struggle with the formula for the economic governance of Europe and new instruments of economic governance, developed together with the Council President, with the aim of leveling off the differences inside the euro zone and approximating its functioning to the theoretical principles of an optimum currency area (Wojciechowski, 2012). This example confirms that the rotating presidency is less and less required in the new institutional shape of the EU, which translates into decreasing journalist interest in its activity. 
Paweł Świeboda (2011) claims that Poland aimed to convince its partners that she continues to support the Union in the form accepted at the time of accession. Hence the defense of the internal market and suggestions to continue its liberalization, for instance in services as well as maintaining European cohesion and a revived EU neighborhood policy, in particular in its Eastern dimension.

It is arguable how to assess the activities and their media reflection as regards the failure to include Bulgaria and Romania in Schengen zone, and the response of Poland as the presiding state to the strategic turn towards Asia and the Pacific region the United States announced in the last quarter of 2011. This turn "resulted in the altered security policy of the US. While the Middle East continues to play a significant role, that of Europe is diminishing in the eyes of the US. The United States are compelled to face up to the challenges brought by the wave of anti-government movements in the Arab world that have overthrown some US allies and evolved into the civil war in Syria" (Tomaszewski, 2012, p. 9). Another thing is the difficulty in assessing whether Polish diplomacy managed to maintain interest in the Eastern dimension of the neighborhood policy. Initiated by Poland and Sweden, and inaugurated during the Czech presidency of the EU, the Eastern Partnership was a politically well-developed priority ready to be 'politically consummated' during the Polish presidency. Struggling with the crisis, though, in particular in the field of energy, overshadowed the Eastern Partnership Summit in Warsaw.

Adopting the view of the Polish mass media, one should consider the outcomes of the speech that Polish Minister of Foreign Affairs Radosław Sikorski gave in Berlin. While in Germany his address (EurActiv, 2011) was interpreted as pro-European and significant, in view of the post-crisis political order in Europe, the political stage in Poland was divided in their evaluation of Sikorski's statements and their presentation during the Polish presidency. It should be emphasized, though, that his views corresponded with the European debate on the future of the European Union, moderated by Polish and German Ministers of Foreign Affairs.

It appears that of the many external factors that influenced Polish communication about the presidency, some technical circumstances were also instrumental, such as the implementation of the Brussels-national model of the presidency, coupled with the deterritorialization of events: working groups' meetings, formal and informal sessions of the Council and related events. These activities were to reinforce the message and stimulate internal Polish interest in Poland's activity in the European Union. Another 
issue which was utterly beyond the influence of Poland, but which shortened its time of exercising political impact abroad, was holding the presidency in the second half of the year. This is a traditional period of August and December holidays which practically shortens the work of the Council by six weeks, while the number of meetings is comparable to that in the first half of a year.

\section{Conclusions}

In opinion of the government, presented in the Report on the conclusions on Polish presidency of the Council of the European Union, a definite majority of respondents shared the view that all in all it was a successful presidency (Raport, 2012, p. 224). The tone of responses obtained in the survey commissioned by the Polish government from the European Commission members was similar. The survey of commissioners and other officials of EU institutions showed that the presidency took advantage of Polish potential, culture and design.

The interest of the European mass media in the presidency demonstrates that those specializing in EU topics or having a European circulation attached greater importance and paid more attention to Polish activity. The national media provided relatively limited coverage of the presidency, assuming a neutral or positive approach. The issues that were reported most often included the Eastern Partnership, the 'six-pack', the Prime Minister's address to the European Parliament and Minister Sikorski's speech in Berlin (Raport 2012, p. 225). Western European journalists' interest in the presidency was similar to domestic interest. The number of articles and commentaries was larger, but they maintained a neutral, informative attitude. Negative accounts of the overall assessment of the presidency, its significance and effectiveness were only a small proportion there.

This state of affairs could have been influenced by the following factors: (1) the EU was deep in economic crisis; (2) the Council was presided over by a state outside the euro zone; (3) the Lisbon model of the presidency was still being institutionalized; (4) media attention was focused on the anti-crisis political duo of Angela Merkel and Nicolas Sarkozy; (5) the duration of the presidency was shorter, (6) national parliamentary elections were held in Poland, (7) the governments of larger member states had to be coordinated, (8) the European debate on the costs of combating 
the crisis were ongoing, (9) the Polish presidency adopted a mixed model; (10) the events of the Arab Spring were at least partially influential, (12) Poland held the presidency for the first time, (12) this was the first instance of a 'Lisbon' trio; (13) the way the 'Polish trio' was composed, (14) the priorities that predecessors failed to implement were continued, (15) Poles had certain expectations as concerns the presidency; (16) the European and national priorities of the Polish presidency were implemented by way of cooperation inside and outside the Council, (17) the way media coverage was prepared and conducted, (18) the way the Polish team of the presidency's press office was composed.

\section{References}

Dorsch-Jungsberger P. (1995), Nationalbildforschunhg und PR, in: Deutschland in der internationale Kommunikation, ed. W. Mahle, Konstanz, pp. 245-257.

Kucznik M. (1999), Die manipulierte Meinung, Nationale Image Politik und internationale $P R$, Wien.

Leonard M., Popescu N. (2007), A Power audit of EU-Russia relations, European Council of Foreign Relations.

Nowak B. (2012), Ostatnia prezydencja dużych oczekiwań - refleksje po Prezydencji Polski w Radzie UE [The last presidency of high expectations - comments on Poland's the EU Council EU presidency], Raporty i Analizy Centrum Stosunków Międzynarodowych, Warszawa.

Olędzki J. (2001), Komunikowanie w świecie [Communication in the world], Oficyna Wydawnicza Aspra_JR, Warszawa.

Piontek D. (2004), Imagistyka spoleczna, czyli marketing polityczny [Social Imagistics, that is political marketing], in: Media masowe w systemach demokratycznych. Teoretyczne podstawy i praktyczny wymiar komunikowania politycznego [Mass media in democratic systems. Theoretical background and practical dimension of political communication], ed. B. Dobek-Ostrowska, Wrocław, pp. 115-127.

Ryniejska-Kiełdanowicz M. (2007), Public relations w okresie kandydowania do Unii Europejskiej [Public relations in a period of standing for the EU], Wrocław.

Szczerski K. (ed.) (2012), Skuteczność polskiej prezydencji w Unii Europejskiej. Założenia, cele i ich realizacja [Effectiveness of the Polish EU presidency. Assumptions, goals and their realization], Księgarnia Akademicka, Kraków.

Szczerski K., Dulak M. (2012), Prezydencja jako projekt [Presidency as a project], in: Skuteczność polskiej prezydencji w Unii Europejskiej. Założenia, cele i ich realizacja [Effectiveness of the Polish EU presidency. Assumptions, goals and 
their realization], ed. K. Szczerski, Księgarnia Akademicka, Kraków, pp. $19-35$.

Tannous I. (2012), Der Europäische Auswärtige Dienst und die Organisation europäischer Außen- und Entwicklungshilfe: von institutionellen Dissonanzen zur dienstübergreifenden Harmonie?, "Integration", no. 2, Nomos, Berlin, pp. 257-270.

Tomaszewski J. (2012), Zmiany w polityce bezpieczeństwa USA [Changes in the US security policy], "Bezpieczeństwo Narodowe", no. III-IV (23-24).

Tomaszyk M., Grosse G. (2012), Sceptyczny entuzjazm [Skeptical enthusiasm], "Perspektywy europejskie", no. 4(04).

Tomaszyk M. (2012), Polskie przewodnictwo w Radzie UE - próba oceny [Polish EU Council Presidency: an initiatory evaluation], in: Prezydencja Polski w Radzie Unii Europejskiej [Poland's the EU Council Presidency], ed. J. Fiszer, Wydawnictwo Naukowe ISP PAN, Warszawa, pp. 207-230.

Wojciechowski P. (2012), Europejska lekcja zarzadzania gospodarczego [European lesson of economic management], "Polski Przegląd Dyplomatyczny", no. 1(8), pp. 19-45.

Jensen M., Nederguard P. (2012), Erfolgreiche Koordination in turbulenten Zeiten, die dänische Ratspräsidentschaft im ersten Halbjahr 2012, "Integration", no. 4.

Instytut Marki Polskiej (2011), Marka dla Polski. Idea przewodnia. Rozwój tożsamości narodowej Polski [Brand for Poland. Keynote. Development and Poland's national identity] Report no. 1.

Centrum Badania Opinii Społecznej (2011), Przed polska prezydencja w Radzie UE [Before Polish the EU Council Presidency], Komunikat z Badań: BS/68/2011, Warszawa.

Przewodnictwo Polski w Radzie Unii Europejskiej. Raport końcowy z przygotowania i sprawowania prezydencji złożony przez Pelnomocnika Rzadu, raport przyjęty przez Radę Ministrów w dniu 17 kwietnia 2012 r. [Poland's the EU Council Presidency. Final report], Warszawa, April 2012.

MediaMon (2012), Raport medialny. Polska Prezydencja w Unii Europejskiej, okres 1.10-31.12.2011 [Media report. Polish EU presidency, period: 1.1031.12.2011].

\begin{abstract}
Although Poland's presidency of the Council of the European Union concluded almost two years ago, this period of Poland coordinating the work of one of the most significant EU institutions is still the subject of interdisciplinary studies that contribute to the assessment of the new, Lisbon model of European leadership. The paper discusses how the Polish government formulated its communication goals when beginning to prepare for the presidency. How did it define the political message of the presidency?
\end{abstract}


How did it involve citizens in the activities undertaken by the Polish presidency of the EU Council? What domestic and European factors impacted on the evolution of the message of the presidency? How did the priorities of the presidency determine its communication goals? How did this message evolve on account of numerous factors? 